DANMARKS GEOLOGISKE UNDERS ØGELSE

IV. RÆKKE. B D. 4. NR. 7

Geological Survey of Denmark. IV. Series. Vol. 1. No. 7

\title{
Kvantitativ petrografisk \\ Undersøgelse \\ af nogle sjællandske Danienkalksten
}

Af

Gunnar Larsen

English Summary:

Quantitative Petrographic Investigation of some

Danian Limestones

from Sjælland (Denmark)

I kommission hos

C. A. REITZELS FORLAG (JØRGEN SANDAL)

KøBENHAVN 1961 
Andelsbogtrykkeriet i Odense 


\section{Indhold}

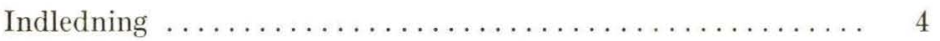

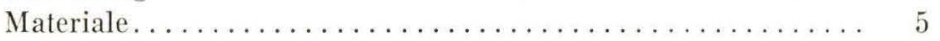

Petrografisk undersøgelse $\ldots \ldots \ldots \ldots \ldots \ldots \ldots \ldots \ldots \ldots \ldots$

Bjergartskomponenter ..................... 7

Bemærkninger om de enkelte tyndsnit . ............ 11

Bjergarternes kvantitative sammensætning . . . . . . . . . 12

Bjergarternes kornstørrelsesfordeling ............. 12

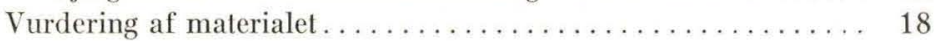

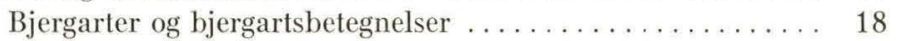

Aflejringsforhold $\ldots \ldots \ldots \ldots \ldots \ldots \ldots \ldots \ldots \ldots \ldots \ldots, 19$

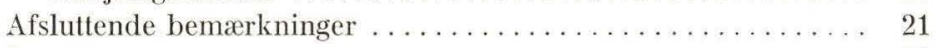

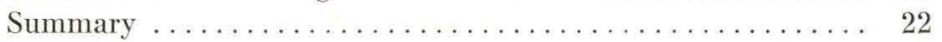

Litteratur.......................... 24 


\section{Indledning}

De danske danienformationers bjergartsmæssige beskaffenhed findes som regel behandlet ret kortfattet $\mathrm{og}$ summarisk i den omfattende litteratur, som beskriver aflejringernes palæontologiske og stratigrafiske forhold. En mere indgående petrografisk karakterisering af bjergarterne er fremlagt i enkelte arbejder, såsom RøRDAM's (1897) undersøgelse af kridtet på Sjælland, afhandlingen om Langbrogårdboringen (Madsen, Ødum, Gry, 1935) samt Gry og SøndergaArd's »Flinteforekomster i Danmark« fra 1958. I sidstnævnte behandles foruden flinten også de kalkformationer, flinten optræder i.

Alle hidtil offentliggjorte undersøgelser af danienkalkens lithologi og petrografi har det fælles, at de behandler emnet kvalitativt beskrivende. Formålet med de undersøgelser, som refereres i det følgende, har været at belyse, hvorvidt kvantitative petrografiske metoder giver væsentlige bidrag til karakterisering af danienkalken.

Den direkte anledning til undersøgelsernes iværksættelse var en henvendelse fra Ole Berthelsen, hvis studier over bl. a. økologiske faktorers indflydelse på bryozofaunaens udvikling i det sjællandske danien (O. Berthelsen, 1962) havde skabt et behov for en nojere karakterisering af visse bjergarters petrografiske forhold.

De tyndsnitspræparater, som analyserne er udført på, er fremstillet af H. BAHNSON. En del af det ved undersøgelsen benyttede apparatur, integrationsbord og blodcelletæller, har været lånt på STATENS BygGeforskningsinstitut's betonlaboratorium. Af handlingens illustrationsmateriale, tegninger og fotografier, er fremstillet af henholdsvis Rigmor Borg og Chr. Westergard.

De nævnte, som har bidraget til arbejdets gennemførelse, bedes modtage min tak. 


\section{Materiale}

Det materiale, de petrografiske undersøgelser er udført på, omfatter en serie på 8 prøver indsamlet af O. BERTHELSEN, som har oplyst følgende vedrørende lokalitet, bjergartsbetegnelse og stratigrafisk placering.

Tabel I. Oversigt over undersogelsesmaterialet.

\begin{tabular}{|c|c|c|c|}
\hline $\begin{array}{l}\text { Prove } \\
\text { nr. }\end{array}$ & Lokalitet & Bjergart & $\begin{array}{l}\text { Stratigrafi } \\
\text { Danienzone }\end{array}$ \\
\hline 1 & $\begin{array}{l}\text { Herfølge kalkgravs nordvæg } \\
2,15 \mathrm{~m} \text { under terræn }\end{array}$ & gruskalk & $\mathrm{D}$ \\
\hline 2 & $\begin{array}{l}\text { Herfølge kalkgravs nordvæg } \\
5,00 \mathrm{~m} \text { under terræn }\end{array}$ & gruskalk & $\mathrm{D}$ \\
\hline 3 & $\begin{array}{l}\text { Herfølge kalkgravs nordvæg } \\
6,10 \mathrm{~m} \text { under terræn }\end{array}$ & bryozokalk & $\mathrm{D}$ \\
\hline 4 & $\begin{array}{l}\text { Herfølge kalkgravs nordvæg } \\
7,15 \mathrm{~m} \text { under terræn }\end{array}$ & bryozokalk & $\mathrm{D}$ \\
\hline 5 & $\begin{array}{l}\text { København; kloakudgravning ved } \\
\text { Hyttehusvej } \\
\text { ca. } 7,00 \mathrm{~m} \text { under terræn }\end{array}$ & kalksandskalk & $\mathrm{D}$ \\
\hline 6 & Fakse kalkbruds nordvæg & bryozokalk & C \\
\hline 7 & Stevns; Boesdal kalkgravs sydvæg & bryozokalk & B \\
\hline 8 & Stevns klint, syd for Højrup kirke & cerithiumkalk & A \\
\hline
\end{tabular}

Af tabellen fremgår, at prøvematerialet omfatter repræsentanter for alle 4 stratigrafiske zoner, samt for størstedelen af de bjergartstyper, som kendes fra danienet på Sjælland. Det skal dog understreges, at det ved udvælgelsen af analyseprøver ikke har været tilsigtet at fremskaffe et fuldt repræsentativt udsnit af den sjællandske danienlagseries bjergartsfølge; der er ved udvælgelsen af hver enkelt prøve udelukkende taget hensyn til den føromtalte palæontologiske problemstilling.

De 4 prøver fra Herfølge kan betragtes som et nogenlunde gyldigt udsnit af det yngste danien på denne lokalitet, hvorimod de resterende 4 prøver blot udgør stikprøver fra forskellige lokaliteter.

Lokaliteternes beliggenhed er angivet på det geologiske kort over området, fig. 1 . 


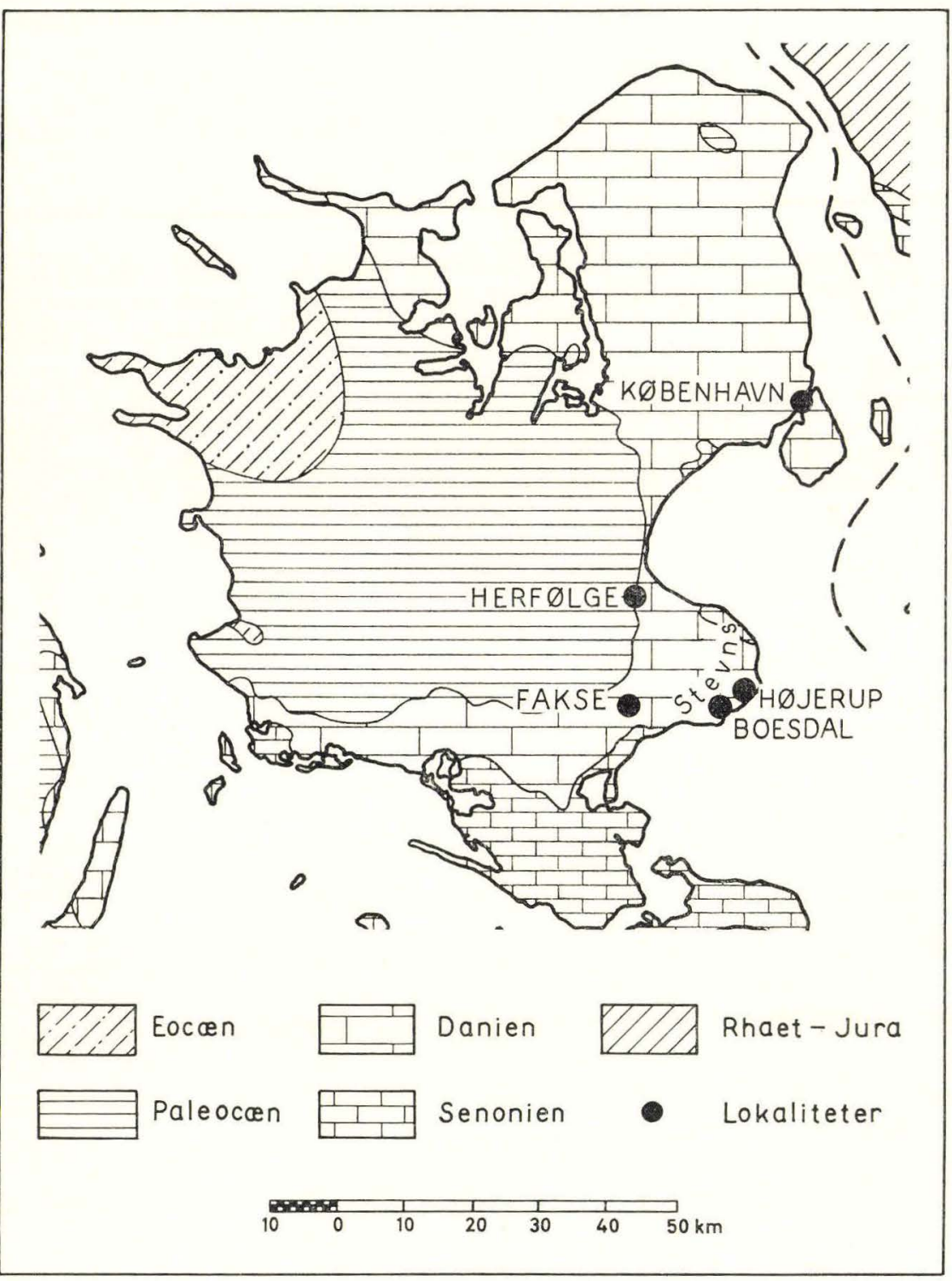

Fig. 1. Geologisk kort, efter Th. Sorgenfrei, 1954.

Geological map, acc. to TH. Sorgenfrei, 1954. 


\section{Petrografisk undersøgelse}

I udenlandsk litteratur findes omtalt forskellige, specielle metoder til undersøgelse af kalksedimenter, eksempelvis bestemmelse af klasticitetsindex og opstilling af særlige texturtyper (Wanless, Ziebell, Ziemba, Carozzr, 1957) eller kombination af petrografiske og kemiske metoder (JaAnusson, 1955; Martna, 1955). Disse metoder er specielle i den forstand, at de er udviklet til undersogelse af kalkbjergarter, men ikke andre sedimenttyper. Ved de her foreliggende undersøgelser har det imidlertid været tilsigtet at betragte kalkstenene i relation til "almindelige" sedimenter, hvorfor analysen har været »almen«, d.v.s. har omfattet petrografisk bestemmelse af prøvematerialets sammensætning og kornstørrelsesforhold.

Til dette brug er der af hver prøve fremstillet et tyndsnit (størrelse ca. $1 \times 2 \mathrm{~cm}$ ), som er betragtet under polarisationsmikroskop. Mikroskopanalysen falder i flg. trin: 1) identifikation og beskrivelse af bjergartskomponenterne, 2) bestemmelse af bjergartskomponenternes mængdeforhold og 3) bestemmelse af komponenternes kornstørrelsesfordeling.

\section{Bjergartskomponenter.}

Med enkelte undtagelser består prøverne udelukkende af kalk. Efter forekomstmåde kan kalkmaterialet naturligt opdeles i tre kategorier: kalkmatrix, organisme-rester og større uorganiske kalkkorn.

Kalkmatrix betegner bjergarternes finkornede grundmasse, som er sammensat af partikler, hvis størrelse er mindre end $20 \mu(1 \mu=0,001 \mathrm{~mm})$. Texturen er granulær. Den ringe partikelstørrelse bevirker, at det ikke i alle tilfælde kan afgøres, hvorvidt materialet er af organisk eller uorganisk oprindelse.

Organismerester. Hertil henføres kalkaggregater, som har partikelstørrelse $>20 \mu, \mathrm{og}$ som ifølge opbygning og omrids tydeligvis repræsenterer skaldele o.l. af organismer. Hyppigst optræder fragmenter af bryozoer, men også brudstykker af andre dyr såsom echinodermer og mollusker er konstateret; desuden er tværsnit af hele foraminiferskaller iagttaget. Echinodermresterne er let kendelige ved at bestå af store enkeltkrystaller af kalcit. De ovrige organismerester er opbygget af finkornet, undertiden fibrøs kalk. Oprindelige hulheder i skalresterne er ofte helt eller delvis udfyldt af kalkmatrix, sjældnere af større, uorganiske kalkkorn.

Større, uorganiske kalkkorn. Herved forstås kalkkorn uden organismestruktur og med partikelstorrelse $>20 \mu$. I nogle tilfælde findes sådanne korn udvokset på echinodermrester, med hvilke de i krystallografisk og optisk henseende udgør en enhed. I andre tilfælde ser kornene ud til at være udskilt i oprindelige 


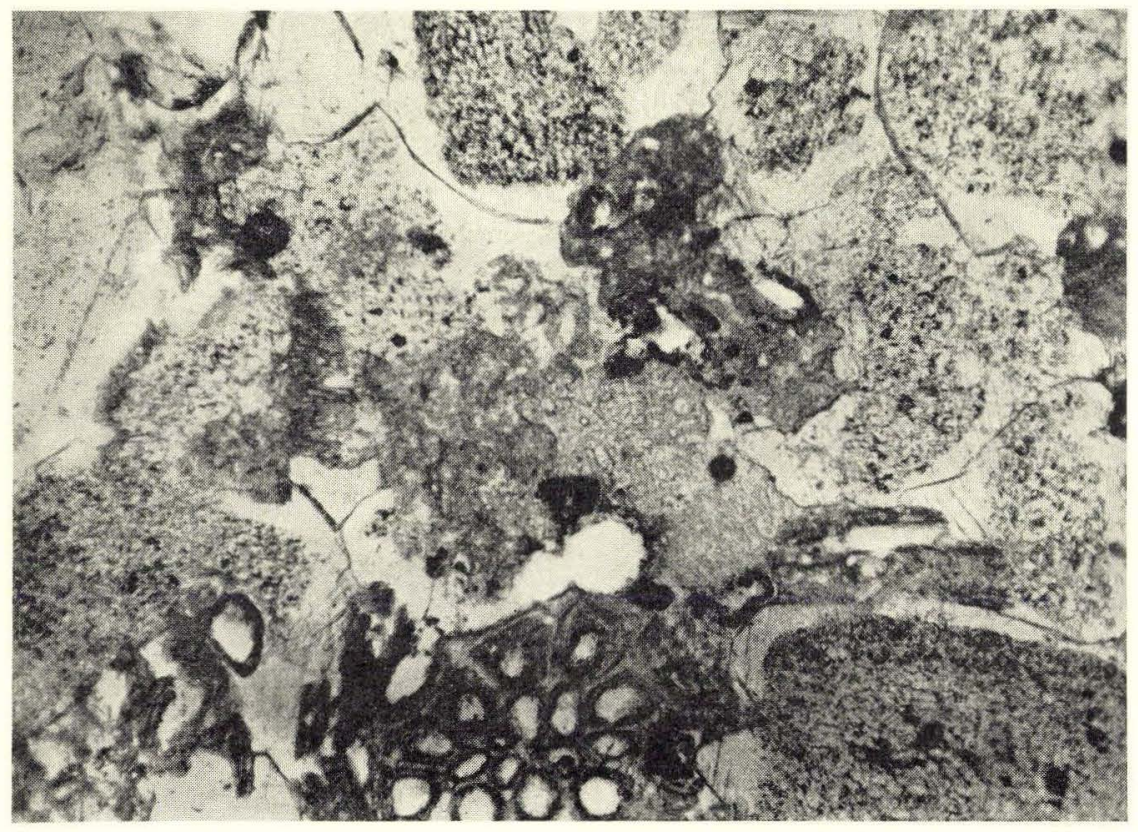

Fig. 2. Prøve nr. 1; Herfølge. ( || Nic, ×80.)

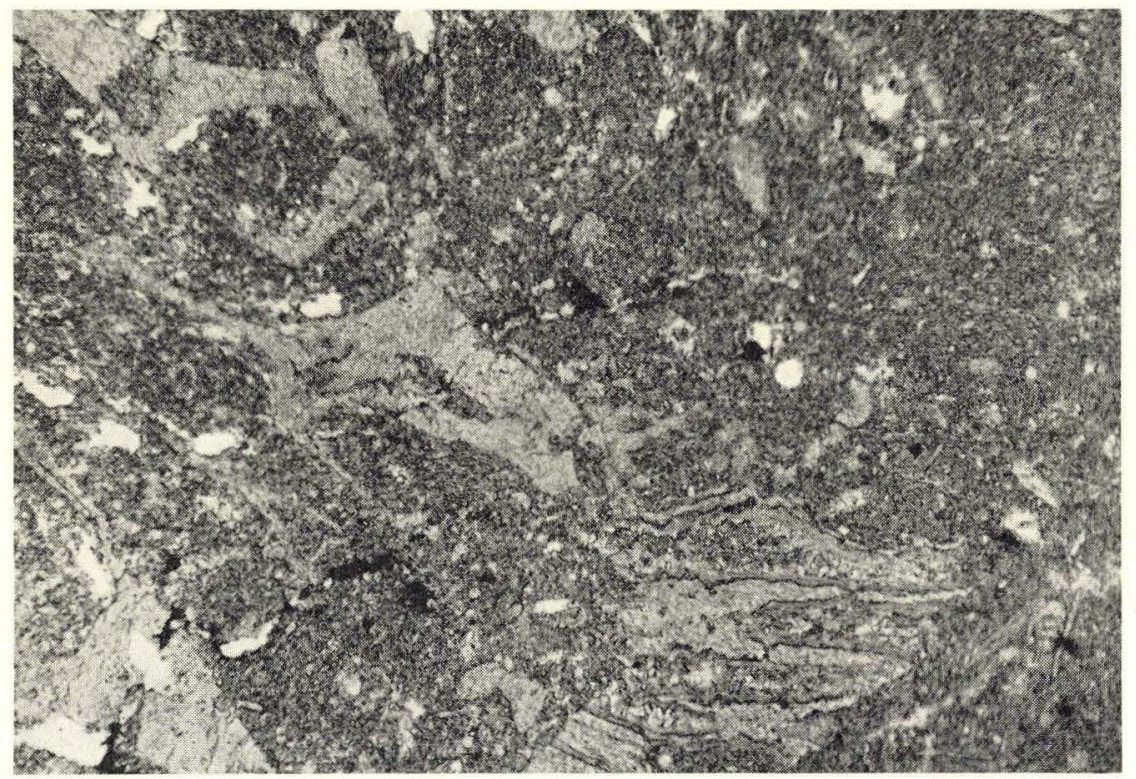

Fig. 3. Prøve nr. 3; Herfølge. ( $\|$ Nic, $\times 80$.) 


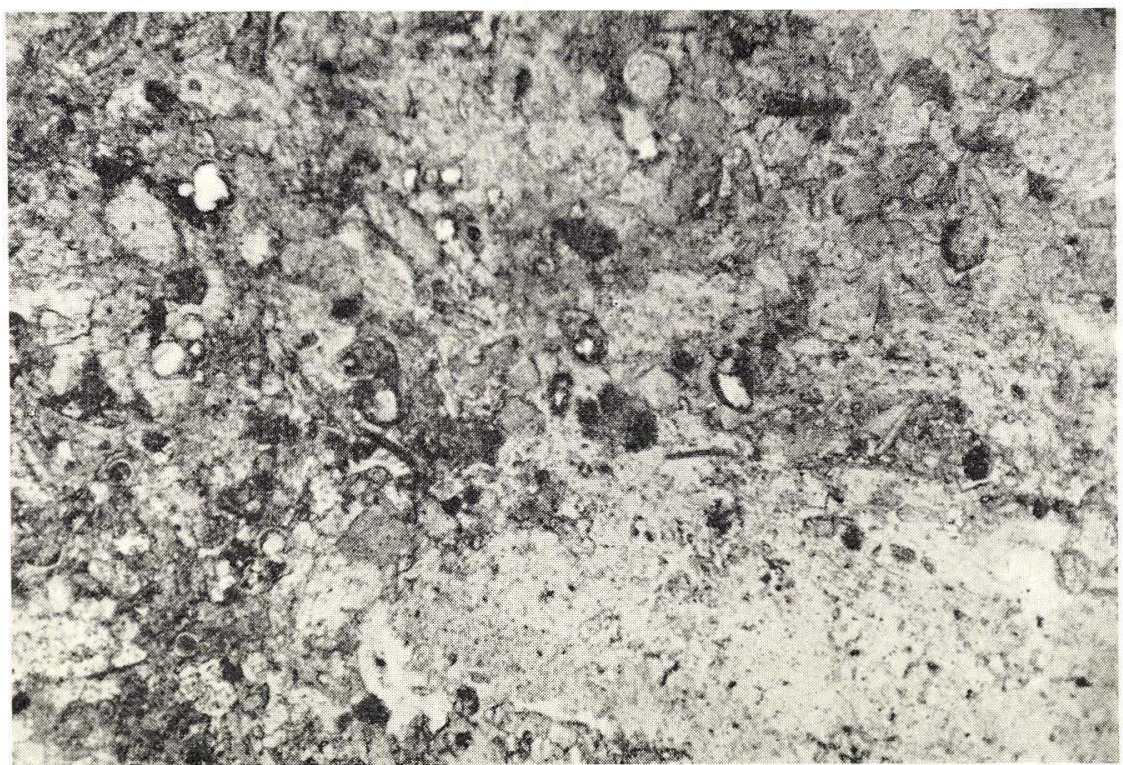

Fig. 4. Prøve nr. 5; København. ( $\|$ Nic, $\times 80$.)

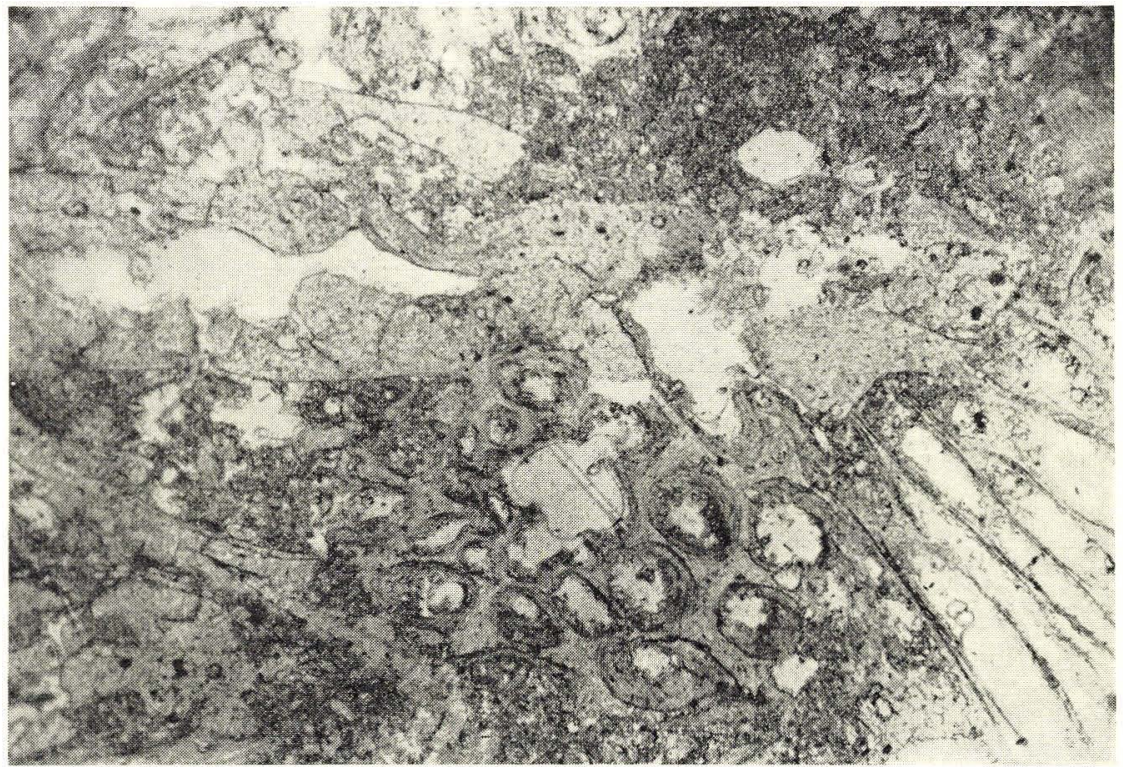

Fig. 5. Prøve nr. 6; Fakse. (\| Nic, $\times 80$.) 


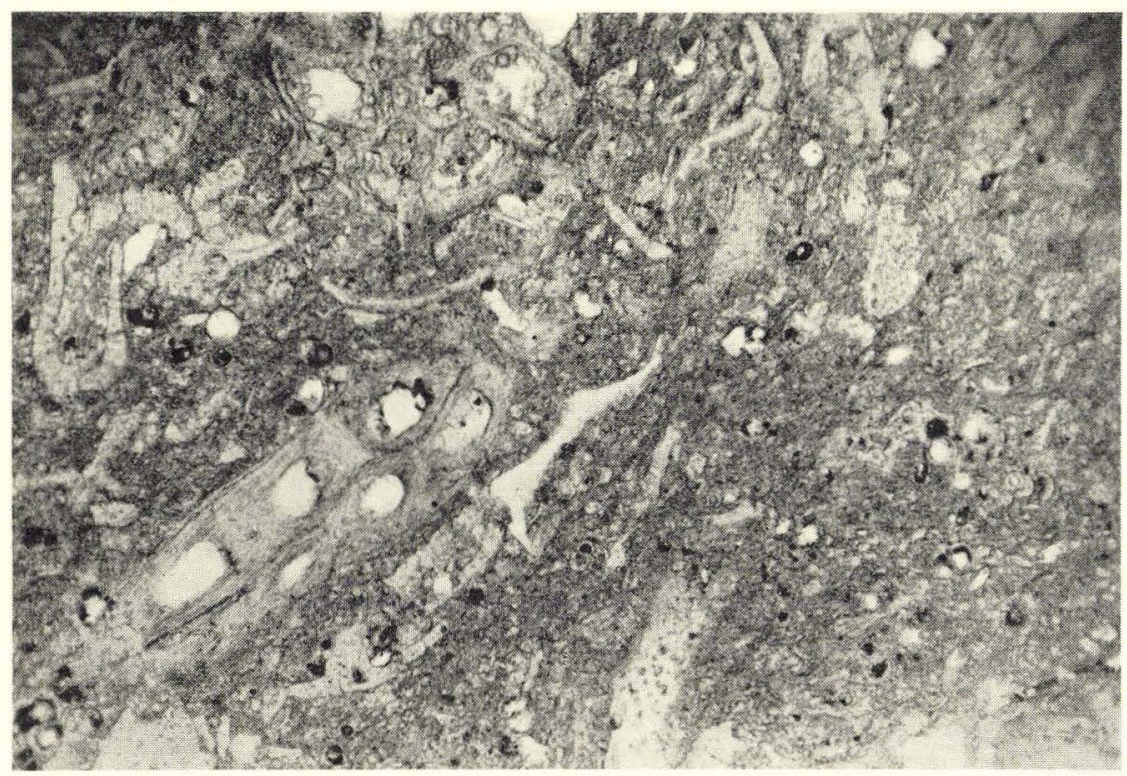

Fig. 6. Prove nr. 7; Boesdal. ( $\|$ Nic, $\times 80$.)

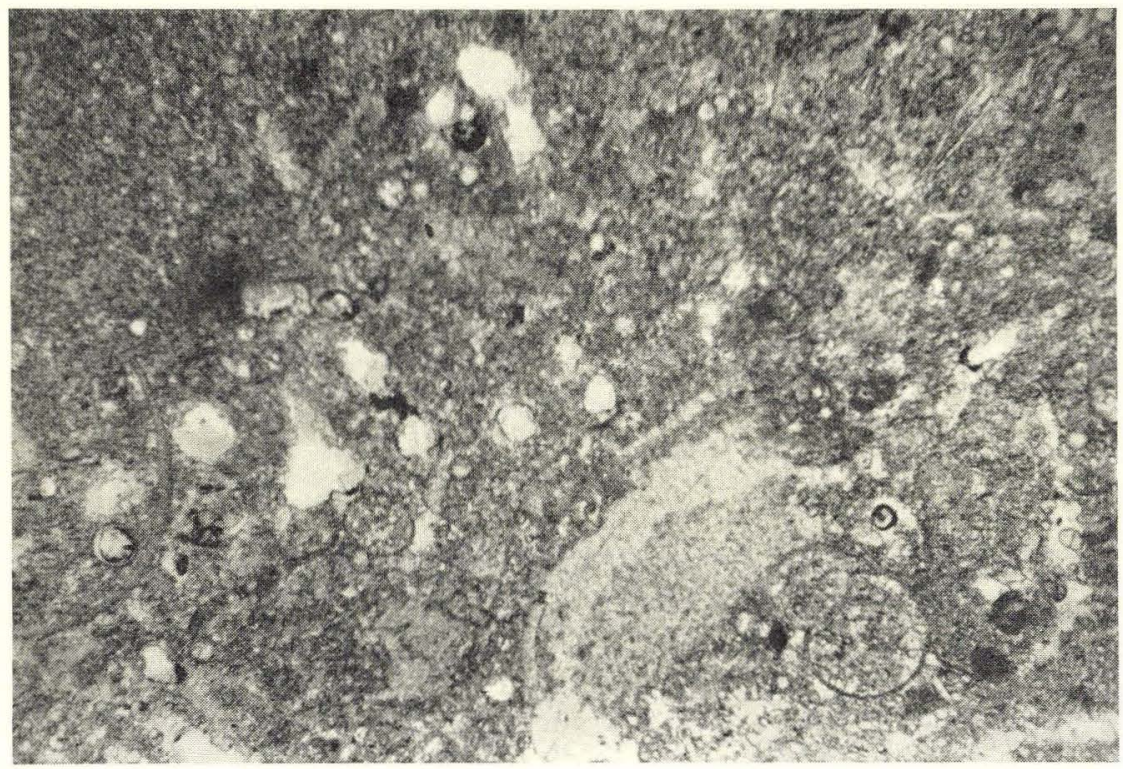

Fig. 7. Prøve nr. 8; Højerup. (\| Nic, $\times 80$. 
porer i og mellem andre organismefragmenter. Kornene er ofte anhedrale, men enkelte idiomorfe krystaller optræder. Efter forekomstmåden må de uorganiske kalkkorn antages at være udskilt i bjergarterne efter aflejringen, d.v.s. diagenetisk.

Andre bestanddele end kalk er til stede i prøverne nr. 1 og 2 . I begge er glaukonit konstateret forekommende som spredte, diffust begrænsede småformationer. I prover nr. 1 forekommer desuden enkelte korn af kvarts og kvartsit. Disse har velafrundet, glat overflade.

\section{Bemærkninger om de enkelte tyndsnit.}

Prøve nr. 1 (fig. 2). Porøs bjergart væsentligst bestående af organismerester og større uorganiske kalkkorn. Organismeresterne, som omfatter repræsentanter for bryozoer, echinodermer, mollusker og foraminiferer, fremtræder undertiden med svagt kantslidte konturer. En del af mellemrummene mellem organismefragmenterne er udfyldte med større, uorganiske, overvejende anhedrale kalcitkorn; dog er krystalflader udviklet på korn, som udgor dele af porevægge. Kalkmatrix findes i ringe mængde, især som belægning på indre og ydre overflader af organismefragmenter. Glaukonit er til stede som spredte, små, overvejende diffust begrænsede formationer, ofte indesluttet i storre, uorganiske kalkkorn. Endelig findes enkelte, afrundede kvarts- og kvartsitkorn.

Prøve nr. 2. Svarer i alt væsentligt til prøve nr. 1, dog er prøve nr. 2 mindre porøs, og kvartskorn er ikke iagttaget.

Prøve nr. 3 (fig. 3). Ret tæt, matrixrig bjergart indeholdende en del organismerester, som ikke ser ud til at være præget af slid. De største fragmenter består af bryozoer og echinodermer. Næsten samtlige oprindelige kaviteter i organismefragmenterne er matrixfyldte.

Prøve nr. 4. Svarer nøje til prove nr. 3.

Prøve nr. 5 (fig. 4). Udpræget tæt bjergart bestående af matrix, organismerester, og større, uorganiske kalkkorn. Sidstnævnte er anhedrale og optræder med stor hyppighed udfyldende mellemrum mellem de andre bestanddele, hvorved bjergarten făr et krystallinsk udseende. Blandt organismeresterne træffes en del foraminiferskaller. Kun få bryozoer er til stede. Der er stedvis konstateret symptomer på afslidninger af skaloverflader.

Prøve nr. 6 (fig. 5). Højporøs bjergart bestående overvejende af store organismefragmenter, især bryozoer. Kalkmatrix udfylder en del af mellemrummene mellem organismeresterne samt en del af disses interne kaviteter. Organismeresternes overflader ser ikke ud til at være præget af afslidninger.

Prøve nr. 7 (fig. 6). Forholdsvis tæt, organismerig bjergart; bryozoer fremherskende. Kalkmatrix udfylder størstedelen af mellemrummene mellem og hulrummene i fossilfragmenterne; dog indeholder enkelte af hulrummene større, uorganiske kalkkorn. Ingen af organismeresterne ser ud til at være præget af slid.

Prøve nr. 8 (fig. 7). Ret tæt bjergart bestående af kalkmatrix og forholdsvis mange, overvejende ret små organismerester, især foraminiferer, mollusker og brachiopoder samt enkelte bryozoer. 


\section{Bjergarternes kvantitative sammensætning.}

Metode. Ovennævnte bjergartskomponenters relative hyppighed i de enkelte prøver er undersøgt ved integration. Hertil er anvendt et Leitz integrationsbord. Den målte distance udgør for hvert tyndsnit ca. $4-5 \mathrm{~cm}$ fordelt på 5 linier.

Resultat. Den ved integrationen fundne procentiske hyppighedsfordeling af bjergartskomponenterne er anført i tabel II. Her er tillige angivet det målte porevolumen udtrykt i procent af hele materialet, d.v.s. fast stof + hulrum. Det skal bemærkes, at det anførte porevolumen kun refererer til det under mikroskopet synlige, hvorimod den ultramikroskopiske porøsitet, som antagelig gør sig gældende i såvel matrix som organismerester, af indlysende grunde ikke er inkluderet heri.

Af tabellen ses, at prøverne 1 og 2, som indbyrdes er ret ensartede, afviger afgørende fra de øvrige prøver, bl.a. ved at have et meget ringe indhold af finkornet matrix. Prøverne 3 og 4 viser sig at være indbyrdes identiske med hensyn til den kvantitative sammensætning; de skiller sig tydeligt ud fra det resterende materiale, ved at kalkmatrix er den helt dominerende bestanddel. Nr. 5 er særpræget ved

Tabel II. Bjergarternes kvantitative sammensatning.

+ : udgør mindre end $1 \%$

- : ikke konstateret.

\begin{tabular}{|c|c|c|c|c|c|c|c|}
\hline & \multirow[b]{2}{*}{ Prøve nr. } & \multicolumn{5}{|c|}{ Procentisk hyppighed af komponenterne } & \multirow{2}{*}{$\begin{array}{l}\text { Porevolu- } \\
\text { men i } \\
\text { procent af } \\
\text { hele } \\
\text { bjergarten }\end{array}$} \\
\hline & & $\begin{array}{c}\text { Kalk } \\
\text { matrix }\end{array}$ & $\begin{array}{c}\text { Orga- } \\
\text { nisme- } \\
\text { rester }\end{array}$ & $\begin{array}{l}\text { Større } \\
\text { uorg. } \\
\text { kalkkorn }\end{array}$ & Glaukonit & $\begin{array}{c}\text { Kvarts og } \\
\text { kvartsit }\end{array}$ & \\
\hline 1 & (Herfølge) & 4 & 43 & 53 & + & + & 7 \\
\hline 2 & - & 9 & 55 & 36 & + & - & 4 \\
\hline 3 & - & 72 & 28 & - & - & - & 1 \\
\hline 4 & - & 72 & 28 & - & - & - & 1 \\
\hline & (København). & 36 & 40 & 24 & - & - & - \\
\hline 6 & (Fakse) ...... & 33 & 67 & - & - & - & 19 \\
\hline 7 & (Boesdal)..... & 39 & 61 & - & - & - & 3 \\
\hline & (Højerup). & 30 & 70 & - & - & - & 5 \\
\hline
\end{tabular}

at indeholde betydelige mængder af alle tre kalkkomponenter. De sidste tre prøver $(6,7,8)$ udgør en nogenlunde afgrænset gruppe karakteriseret ved, at organismeresterne mængdevis dominerer over matrixen. Hertil skal dog bemærkes, at såfremt prøve 6's porevolumen havde været matrixfyldt, ville denne repræsentere en overgangsform mellem henholdsvis prøverne 3 og 4 og prøverne 7 og 8 .

\section{Bjergarternes kornstørrelsesfordeling.}

Metode. Komponenternes størrelsesfordeling er bestemt på grundlag af målinger af partikeldiametre i tyndsnittene. Analysen er udført på den måde, at der i hvert præparat måltes største lineære udstrækning af hver af 200 korn, som passerede okularcentret under præparatføring med korsbord.

Disse målinger omfatter udelukkende partikler $>20 \mu$, d.v.s. kalkmatrixen er ikke indbefattet heri. Årsagen hertil er den, at korngrænserne i den finkornede 
grundmasse er vanskelige at erkende som følge af, at partikelstørrelsen er mindre end præparattykkelsen (ca. 20-30 $\mu$ ).

De ved målingerne fundne partikeldiametre er grupperet i flg. kornstørrelsesklasser:

$20-50,50-100,100-200,200-500,500-1000,1000-2000,2000-5000 \mu$. Hyppigheden af korn i disse klasser er dernæst bestemt ved tælling under anvendelse af blodcelletæller.

Som nævnt omfatter disse kornmålinger udelukkende bjergartsbestanddele, hvis størrelse overstiger $20 \mu$. For at belyse kornstørrelsesfordelingen i bjergarten som helhed er kalkmatrixen, d.v.s. partikler $<20 \mu$, betragtet som en kornstørrelsesfraktion. Dennes hyppighed er tidligere bestemt ved integration (tabel II). For hver prøve er de ved kornmåling og -tælling fundne data derpå sat lig 100 minus kalkmatrixens hyppighedsprocent (tabel II), hvorefter den procentiske fordeling af materialet i flg. kornstørrelsesklasser beregnedes:

$<20,20-50,50-100,100-200,200-500,500-1000,1000-2000,2000-5000 \mu$.

Den herved udledede kornstørrelsesfordeling angiver ikke kalkbjergarternes virkelige korngradering, idet en del af de målte partikler må anses for at repræsentere excentrisk beliggende snit i større korn. For at gøre analysematerialet sammenligneligt med sigteanalyseresultater er der foretaget en videre bearbejdelse under anvendelse af Friedman's (1957) "Graph paper for determining sieve-size distribution from thin-section data", et diagram, som er udformet således, at ordinaten angiver den kumulative hyppighedsprocent, medens abscissen omfatter to kornstørrelsesskalaer, én for tyndsnitsdata og én for sigtedata. I dette diagram er sumkurverne for de fundne, tilsyneladende kornstørrelsesfordelinger indtegnet og de hertil ækvivalerende sigtekurver aflæst.

Resultat. Den ved kornmåling og -tælling fundne kornstørrelsesfordeling for partikler større end $20 \mu$ er anfort i tabel III.

Tabel III. Kornstorrelsesfordeling for partikler $>20 \mu$.

\begin{tabular}{|c|c|c|c|c|c|c|c|}
\hline \multirow{2}{*}{ Prøve nr. } & \multicolumn{7}{|c|}{ Procentisk hyppighed af kornstørrelsesfraktioner $(\mu)$} \\
\hline & $20-50$ & $50-100$ & $100-200$ & $200-500$ & $500-1000$ & $1000-2000$ & $2000-5000$ \\
\hline 1 (Herfølge). & 3 & 5 & 17 & 48 & 23 & 4 & + \\
\hline $2 \quad-\quad \ldots \ldots$ & 1 & 9 & 25 & 49 & 12 & 3 & 1 \\
\hline$\ldots \ldots$ & 24 & 18 & 23 & 29 & 4 & 1 & 1 \\
\hline$\ldots \ldots$ & 38 & 32 & 16 & 13 & 1 & - & - \\
\hline 5 (København).... & 38 & 34 & 17 & 7 & 2 & 2 & - \\
\hline 6 (Fakse) & 15 & 17 & 12 & 28 & 16 & 6 & 5 \\
\hline 7 (Boesdal)....... & 28 & 32 & 16 & 19 & 5 & - & - \\
\hline 8 (Højerup) . . . . . & 25 & 31 & 34 & 8 & 2 & - & - \\
\hline
\end{tabular}

For prøverne $3,4,6,7$ og 8 's vedkommende består kornmaterialet $>20 \mu$ udelukkende af organismerester (jvf. tabel II), medens det i prøverne 1, 2 og 5 omfatter såvel organismefragmenter som uorganiske korn. Under henvisning til, at de uorganiske korn antagelig er udskilt i bjergarten efter sedimentationen og således næppe afspejler karakteristika ved aflejringsprocessen, er det fundet hensigts- 


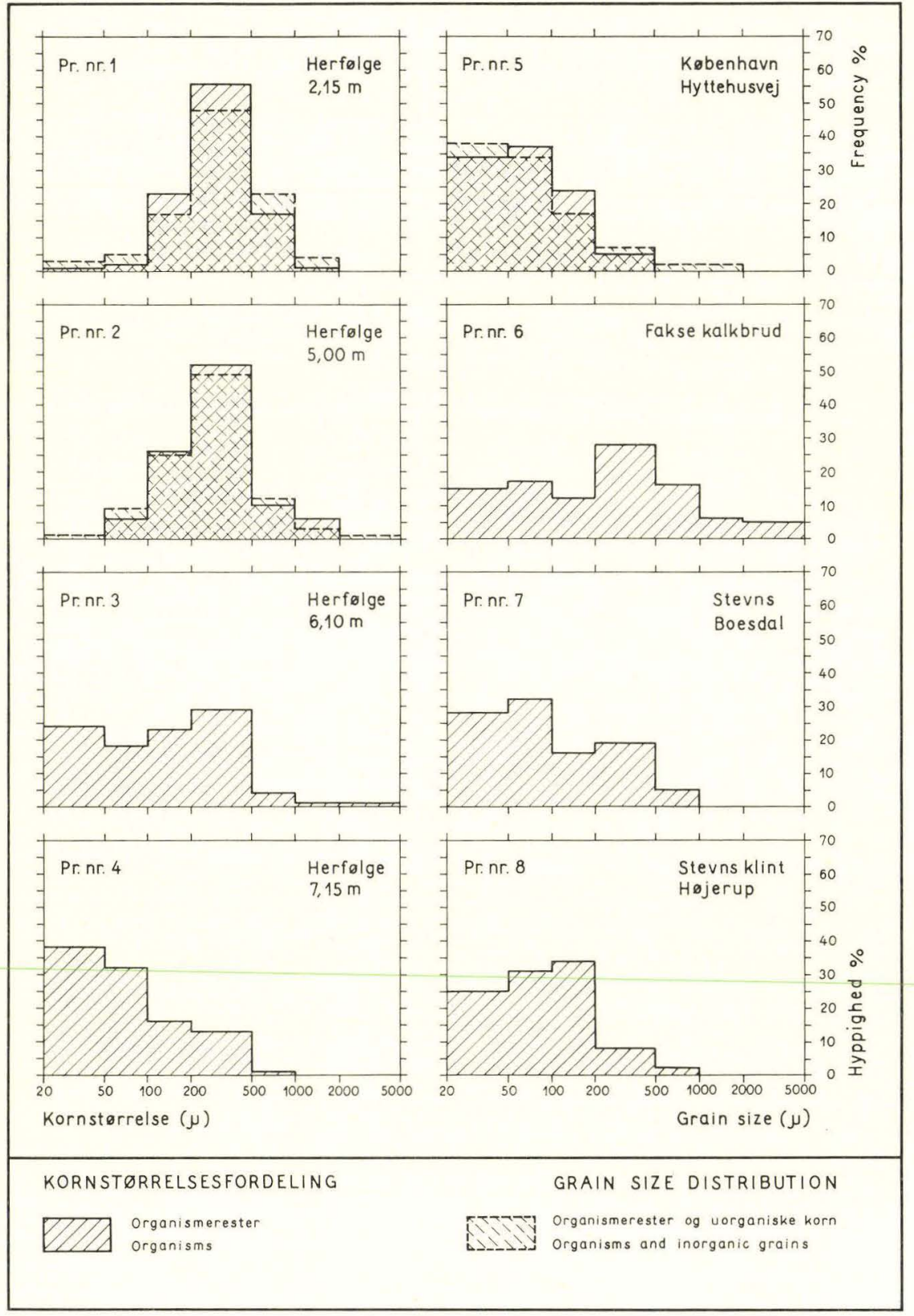

Fig. 8. 
mæssigt for hver af disse tre prøver at udfore en serie kornstørrelsesmålinger omfattende organismefragmenter alene. Resultatet heraf er vist i tabel IV.

Tabel IV. Kornstorrelsesfordeling for organismefragmenter alene.

\begin{tabular}{|c|c|c|c|c|c|c|c|}
\hline \multirow{2}{*}{ Prøve nr. } & \multicolumn{7}{|c|}{ Procentisk hyppighed af kornstørrelsesfraktioner $(\mu)$} \\
\hline & $20-50$ & $|50-100|$ & $100-200$ & $|200-500|$ & $500-1000$ & $1000-2000$ & $2000-5000$ \\
\hline 1 (Herfølge). & 1 & 2 & 23 & 56 & 17 & 1 & - \\
\hline 2 & - & 6 & 26 & 52 & 10 & 6 & - \\
\hline 5 (København).... & 34 & 37 & 24 & 5 & - & - & - \\
\hline
\end{tabular}

I fig. 8 er tabellerne III og IV's data fremstillet grafisk. Heraf ses, at prøverne 1 og 2 har en velsorteret, unimodal kornstørrelsesfordeling. I proverne 3, 6 og 7 er fordelingen bimodal og sorteringen ringe. 4,5 og 8 stiller sig intermediært for så vidt som kornfordelingen er unimodal, men sorteringen ret ringe.

Yderligere fremgår, at der i proverne 1, 2 og 5 ikke kan påvises iøjnefaldende forskelle med hensyn til kornstorrelsesfordelingen for henholdsvis organismefragmenter alene og organismefragmenter + uorganiske korn; dog spores der en tendens til, at sidstnævnte korngruppe i højere grad end forstnævnte gor sig gældende i såvel de fineste som de groveste fraktioner. Dette er muligvis til dels en folge af, at en betydelig del af den uorganiske kalk optræder som udvoksning på visse organismerester, echinodermer (jvf. p. 7), men desuden må den statistiske usikkerhed på måleresultaterne tillægges en vis betydning. - Da graderingsforholdene som nævnt i princippet er ens for de to kornkategorier, er det fundet fuldt forsvarligt $\mathrm{i}$ den videre bearbejdelse af materialet for prøverne 1,2 og 5 's vedkommende at se bort fra de særlige målinger, som omfattede organismerester alene.

En beregning af kornstørrelsesfordelingen for materialet som helhed er foretaget på grundlag af de i tabellerne II og III foreliggende målinger med det i tabel $\mathrm{V}$ viste resultat.

Tabel V. Kornstorrelsesfordeling beregnet på grundlag af labellerne II og III.

\begin{tabular}{|c|c|c|c|c|c|c|c|c|c|}
\hline \multirow{2}{*}{\multicolumn{2}{|c|}{ Prøve nr. }} & \multicolumn{8}{|c|}{ Procentisk hyppighed af kornstorrelsesfraktionerne $(\mu)$} \\
\hline & & $\begin{array}{c}<20 \\
(\text { matrix })\end{array}$ & $20-50$ & $50-100$ & $100-200$ & $200-500$ & $\begin{array}{l}500- \\
1000\end{array}$ & $\begin{array}{c}1000- \\
2000\end{array}$ & $\begin{array}{c}2000- \\
5000\end{array}$ \\
\hline 1 & (Herfolge). & 4 & 3 & 5 & 16 & 46 & 22 & 4 & + \\
\hline 2 & $-\quad \ldots$ & 9 & 1 & 8 & 23 & 45 & 11 & 3 & 1 \\
\hline 3 & - & 72 & 7 & 5 & 6 & 8 & 1 & + & + \\
\hline 4 & - & 72 & 10 & 9 & 4 & 4 & + & - & - \\
\hline & (København) & 36 & 24 & 22 & 11 & 4 & 1 & 1 & - \\
\hline 6 & (Fakse) .... & 33 & 10 & 11 & 8 & 19 & 11 & 4 & 3 \\
\hline 7 & (Boesdal) ... & 39 & 17 & 20 & 10 & 12 & 3 & - & - \\
\hline & (Højerup).. & 30 & 18 & 22 & 24 & 6 & 1 & - & - \\
\hline
\end{tabular}

Under anvendelse af Friedman's grafiske metode er dette talmateriale omformet til de i fig. 9 viste summationskornkurver. Disse skulle som nævnt være sande i den forstand, at de skulle være identiske med kornkurver fremstillet ved sigtning 
af løse sedimenter med samme kornstørrelsesforhold som de her foreliggende, hærdnede kalkbjergarters.

Af figuren ses, at prøverne 1 og 2 tilsammen udgør en velafgrænset gruppe karakteriseret ved relativt stor gennemsnitskornstørrelse og god sortering. Dette er yderligere belyst ved nedenstående angivelse af størrelsen af flg. parametre a) medianen (Md), som er den kornstørrelse, der modsvarer hyppigheden $50 \%$ i diagrammet, b) første og tredie quartilie $\left(Q_{1} \circ \mathrm{g}_{3}\right)$, hvorved forstås de til hyppighederne henholdsvis $25 \%$ og $75 \%$ svarende kornstørrelser samt c) Trask's sorteringskoefficient, So $=\sqrt{\mathrm{Q}_{3} / \mathrm{Q}_{1}}$ (se Krumbein \& Pettijohn, 1938, p. 230).

$\begin{array}{lcccc} & \begin{array}{c}\mathrm{Md} \\ (\mathrm{mm})\end{array} & \begin{array}{c}\mathrm{Q}_{1} \\ (\mathrm{~mm})\end{array} & \begin{array}{c}\mathrm{Q}_{3} \\ (\mathrm{~mm})\end{array} & \text { So } \\ \text { Prøve nr. 1 } & 0,27 & 0,14 & 0,45 & 1,789 \\ \text { Prøve nr. 2 } & 0,21 & 0,11 & 0,37 & 1,844\end{array}$

Til sammenligning skal angives, at sedimenter med So $<2,5$ regnes for velsorterede, medens sådanne, hvis So overstiger 4,5, karakteriseres som dårligt sorterede (Twenhofel \& Tyler, 1941). Ifølge disse definitioner må prøverne $1 \mathrm{og}$ 2 regnes for endog særdeles velsorterede.

For de øvrige prøver kan sorteringskoefficienten ikke udregnes, på grund af at $\mathrm{Q}_{1}$ og i visse tilfælde også Md ikke er repræsenteret i diagrammet. Af kurveforløbet alene fremgår dog, at disse prøver dels er mere finkornede, dels har ringere sortering end de to førstnævnte. Ydermere ses, at der er en tendens til, at prøverne $5 \mathrm{og}$ 8 er bedre sorteret end 3, 4, 6 og 7 . 


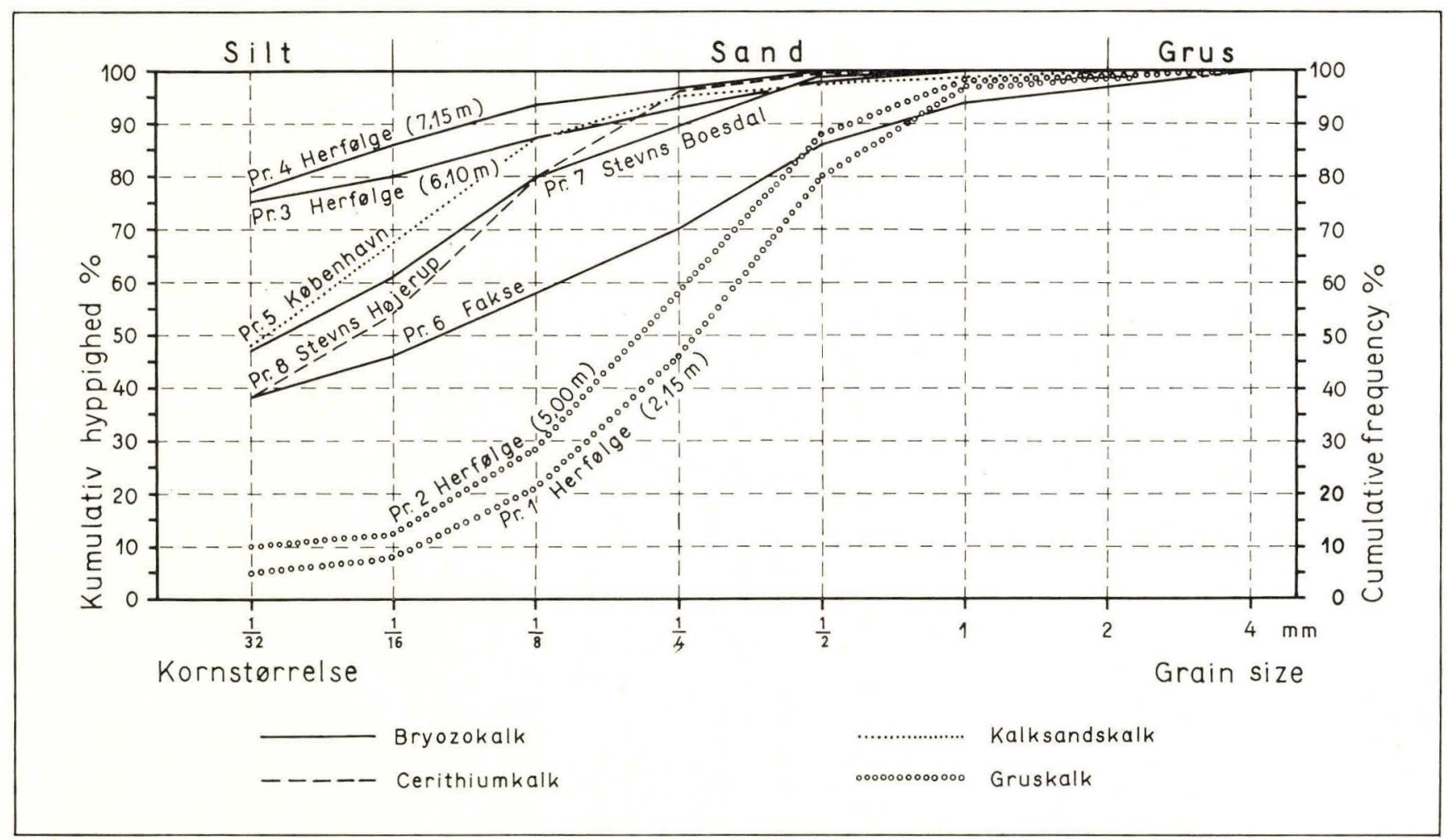

Fig. 9. Kornkurvediagram. - Grading chart. 


\section{Vurdering af materialet}

På grundlag af ovenstående karakterisering af undersøgelsesmaterialets petrografiske beskaffenhed skal der fremsættes nogle betragtninger vedrørende bjergarterne og deres dannelsesforhold.

\section{Bjergarter og bjergartsbetegnelser.}

De bjergartstyper, undersøgelsen har omfattet, går som nævnt under betegnelserne: gruskalk, bryozokalk, kalksandskalk og cerithiumkalk.

Gruskalken er en udpræget klastisk bjergart, hvilket fremgår af såvel den gode sortering som kalkkornenes afslidte overflader. Betegnelsen gruskalk tager sig iøvrigt uheldig ud i betragtning af, at der i de undersøgte prøver kun findes ca. $1 \%$ korn af grusstørrelse (d.v.s. $>2 \mathrm{~mm}$ ); ca. $90 \%$ er af sandstørrelse $\left(2-\frac{1}{16} \mathrm{~mm}\right)$, og de resterende ca. $10 \%$ er endnu mere finkornede. Ifølge disse data forekommer det rigtigere at knytte betegnelsen kalksand til denne bjergarttype, og under henvisning til forekomststedet kan aflejringen entydigt angives som Herfølge kalksandet, en betegnelse, der er i overensstemmelse med HedBERG's (1954) terminologiprincip (se også Troelsen og Sorgenfrei, 1956). Endelig kan bemærkes, at den engelske betegnelse calcarenit (Реттыон, 1949, p. 300) er fuldt dækkende for denne bjergart.

Bryozokalk er i undersøgelsesmaterialet repræsenteret ved fire prøver. Selv om disse er indbyrdes noget forskellige med hensyn til sammensætningen udviser de dog et betydeligt fælles præg ved at 1) sorteringen er yderst ringe, 2) materialet består af kalkslam (matrix) og organismefragmenter (væsentligst bryozoer) og 3) organismefragmenterne øjensynlig ikke er præget af slid. Ifølge disse træk kan bryozokalken tilsyneladende bedst klassificeres som en autokton bjergart. De registrerede forskelle mellem prøverne viser, at bryozokalken er en heterogen bjergartgruppe, som omfatter flere forskellige petrografiske typer. Der skal dog ikke på dette sted fremsættes yderligere kommentarer hertil under henvisning til, at det ikke foreligger tilstrækkelig klarlagt, hvorledes prøvematerialet repræsenterer bryozokalkformationerne.

Prøven af kalksandskalk fra København må ligesom prøverne nr. 1 og 2 fra Herfølge karakteriseres som klastisk kalksten. Dette fremgår af kalkkornenes afslidte overflader, men også materialets sorteringsgrad kan passe med denne opfattelse. I den undersøgte prøve udgør korn af sandstørrelse kun ca. $30 \%$ af bjergarten, medens de resterende $70 \%$ har mindre kornstørrelse. Betegnelsen kalkfinsand synes derfor at være i bedre overensstemmelse med de petrografiske forhold. Inden for kalksandsaflejringerne i Københavnsområdet må kornstørrelsesforholdene dog antages at variere så betydeligt, at den her undersøgte prøve ikke kan regnes 
for fuldt repræsentativ. Dette fremgår bl.a. af, at H. Gry (1935, p. 24) anfører, at kalksandet ved basis af paleocæenet i København området har en ensartet kornstørrelse varierende mellem $0,10 \mathrm{og} 0,15 \mathrm{~mm}$. Dette svarer til, at bjergarten i petrografisk henseende virkelig er kalksand. For at skelne denne aflejring fra Herfølge forekomsten foreslås indført betegnelsen København kalksandet. Endelig skal nævnes, at den undersøgte prøve ved sit store indhold af foraminiferskaller tilsyneladende har betydelig lighed med den af RøRDam (1897, p. 70) beskrevne foraminiferkalk.

Cerithiumkalken fra Stevns klint synes at have træk fælles både med de klastiske og med de autoktone kalksten. Sorteringsgraden svarer meget godt til klastiske bjergarters, medens det autoktone præg fremkommer ved, at der ikke er iagttaget afslidningsfænomener på kornoverfladerne. Rosenkrantz og Wienberg Rasmussen (1960, p. 5) har beskrevet cerithiumkalken som »calcareous silt devoid of bryozoans «. Bortset fra, at enkelte bryozofragmenter er til stede i den her undersogte prøve, dækker betegnelsen ret godt de bjergartskarakterer, som den petrografiske analyse har fremdraget.

Denne omtale af de undersøgte danienbjergarter skal suppleres med en bemærkning om, at forfatteren tilslutter sig ØDum's (1926, p. 25) opfattelse, at coccolitkalken petrografisk bør benævnes slamkalk.

\section{Aflejringsforhold.}

Ifølge de petrografiske egenskaber må man antage, at ret forskelligartede aflejringsforhold er repræsenteret $\mathrm{i}$ det undersogte materiale.

De klastiske bjergarter, d.v.s. kalksandet fra Herfølge og Kobenhavn, er utvivlsomt aflejret af vand i bevægelse. Antagelig har aflejringsområderne udgjort ret lavvandede, kystnære partier i danienhavet, hvor strøm og bølger har sorteret bestanddelene efter kornstørrelse. For Herfølge materialets vedkommende er der med hensyn til graderingsforholdene så betydelig lighed med almindeligt strandsand, at det synes rimeligt at forestille sig, at der her foreligger en egentlig kystzoneaflejring.

Bryozokalkens aflejringsforhold har tilsyneladende afveget ganske betydeligt fra ovennævnte. Kornstørrelsesfordelingen samt kornoverfladens beskaffenhed tyder således på, at partiklerne ikke har været underkastet en sortering efter størrelse. Materialet har derfor næppe været mærkbart påvirket af vandbevægelser, men antagelig kun af tyngdekraften under aflejringen. Hertil skal dog føjes, at det forhold, at hovedparten af bjergarternes grovere bestanddele består af bryozofragmenter, sammenholdt med, at de større aflejringsstrukturer har karakter af bankedannelser, som regnes for at repræsentere voksestederne for bryozokolonierne, tyder på, at der har været så meget bevægelse i vandmasserne, at der ikke blot har været livsbetingelser for bryozokolonierne, men også har kunnet foregå erosion, herunder itubrydning af grendele m.v. på bryozokolonierne. Disse tilsyneladende modstridende vidnesbyrd kan forenes i den opfattelse, at der i aflejringsområdet som helhed har hersket en ret livlig vandbevægelse, men bryozokolonierne har skabt en lævirkning ved selve havbunden, således at aflejringen her kunne foregå praktisk taget uden sortering af materialet. - Den opfattelse, Rørdam (1897) og Johnstrup (1882) for ham gav udtryk for, nemlig at bryozokalken var en "sandstenslignende 
kalksten«, kan næppe gøres gældende for det her undersøgte materiale. Det skal dog understreges, at undersøgelsesmaterialets repræsentativitet formentlig er så ringe, at man ikke på grundlag af dette kan afvise, at der inden for de i det østlige Sjælland så udbredte bryozokalkformationer skulle optræde alle mulige overgangsformer mellem rent sedentære og rent sedimentære aflejringstyper. Visse forskelle spores allerede $\mathrm{i}$ det her undersøgte materiale. Ifølge slamindholdet kan man således antage, at der har været ringere bevægelse i Herfølge bryozokalkens aflejringsområde end i Fakse bryozokalkens. Vedrørende kalkslammets oprindelse skal bemærkes, at de her foreliggende undersøgelser ikke giver et blot nogenlunde sikkert vurderingsgrundlag; slammet kan være kemisk og/eller biogent udfældet og/ cller det kan være af mekanisk oprindelse. Da undersøgelser af recente kalkslamdannelser (se bl. a. FaIrbridge, 1955, p. 44) imidlertid synes at vise, at rent kemiske udfældninger er uhyre sjældne og biogene aflejringer ganske dominerende, skønnes, at også i danientiden har biogene processer, formodentlig i samspil med mekaniske, været hovedårsagen til kalkslamdannelsen.

Sedimentationsforholdene under cerithiumkalkens dannelse ser ud til at repræsentere et intermediært stadium mellem henholdsvis kalksandets og bryozokalkens. Materialets sorteringsgrad tyder på, at komponenterne har været påvirket af vandbevægelse under aflejringen; men bevægelserne har tilsyneladende ikke været så fremtrædende, at de har forårsaget mærkbar afslidning på kornoverfladerne.

Medens prøverne fra Stevns, Fakse og København kun udgør stikprøver, repræsenterer Herfølge materialets fire prøver hovedtrækkene af en aflejringsfølge, der kan angives således:

Prøvedybde 2,15 m: kalksand, velsorteret.

$5,00 \mathrm{~m}$ : kalksand, velsorteret.

$6,10 \mathrm{~m}$ : bryozokalk, stærkt slammet, usorteret.

7,15 m: bryozokalk, stærkt slammet, usorteret.

Heraf ses, at der inden for en vertikal afstand af ca. $1 \mathrm{~m}$ øjensynlig indtræder en markant ændring fra aflejringsforhold med roligt vand til aflejringsforhold med stærkt bevæget vand. Ifølge Rosenkrantz (1937) er de to formationer adskilt af ct konglomeratlag. De nævnte ting (konglomeratet samt den bratte og totale ændring af sedimentationen) tyder på, at der på overgangen mellem de to formationer er indtruffet så gennemgribende ændringer af områdets fysiografi, at årsagen kan antages at være af tektonisk natur.

Endelig skal bemærkes, at de klastiske bjergarter må formodes at være derivater af autoktone kalksten i den forstand, at de består af kalkpartikler, som sikkert for en stor del har udgjort organismedele i bryozobanker (biohermer). I denne forbindelse skal opmærksomheden henledes på den af Rodes W. FAIRBridge (1955, p. 45) indførte lithogenetiske eller om man vil miljømæssige begegnelse »biohermal suite, complex, association or assemblage« hvis dækningsområde angives at være "not only the massive reef-like structures, but also non-reef forming bioherms and biostroms and all the carbonate clastics, precipitates and their derivatives which are spread out by waves and currents, or transported by submarine landslides ...«. Af denne definition fremgår, at betegnelsen "bioherm-komplex" kan benyttes som miljokarakteristik ikke blot for de her undersøgte kalksten, men øjensynlig for hele områdets danienlagserie, bestående af bryozo- og koralbiohermer med indslag af mere eller mindre klastiske kalksedimenter. 


\section{Afsluttende bemærkninger}

Formålet med de petrografiske undersøgelser har været at belyse, hvorvidt analyser ved hjælp af kvantitative metoder gav væsentlige bidrag til karakterisering af kalkens petrografiske beskaffenhed.

Analyserne, samt de vurderinger, der er fremsat på grundlag heraf, synes at pege i retning af, at den talmæssige karakterisering, som fremgår af analyserne, er nyttig for forståelsen af såvel kalkens klassificering som dens genese.

De vurderinger af materialet, som er fremlagt, har begrænset rækkevidde på grund af, at undersøgelsesmaterialet ikke er fuldt repræsentativt for områdets danienkalkaflejringer. En nøjere udredning af disse dannelsers bjergartsudvikling vil kræve analyser af et stort prøvemateriale, hvis repræsentativitet er kendt.

Ved en eventuel fortsættelse af de kvantitative, petrografiske studier over danienkalkstenene bør man eventuelt fremstille større tyndsnitspræparater end de her anvendte, eksempelvis $5 \times 5 \mathrm{~cm}$ (se E. Poulsen, 1957; Andersen \& Huort, 1961), af hensyn til at få de grovere kalkbestanddele bedre repræsenteret i undersogelsesmaterialet. Dette medfører ganske vist den ulempe, at integrationsbord ikke kan anvendes til bestemmelse af bjergartssammensætningen. Man må i så fald benytte sig af andre metoder, eksempelvis den mikroskopiske punktmålingsmetode (G. LARSEN, 1961). 


\title{
Summary
}

\author{
Quantitative Petrographic Investigation of some Danian Limestones \\ from Sjalland (Denmark).
}

All previous investigations on the petrography of Danish Danian limestone are exclusively qualitative investigations. The present quantitative analyses of a few types of limestones is a further contribution to the petrography of the Danian.

Eight samples have been examined, see table I (p. 5). The localities are shown on map fig. 1 (p. 6).

\section{The petrographic analyses.}

A thin section of each sample has been analysed by means of the polarizing microscope.

The sample consist almost exclusively of lime. The lime material may be subdivided in accordance with texture in the following 3 categories:

$$
\begin{array}{ll}
\text { lime with particle size }<20 \mu: & \text { matrix } \\
\text { lime with particle size }>20 \mu: & \left\{\begin{array}{l}
\text { organisms } \\
\text { inorganic grains }
\end{array}\right.
\end{array}
$$

Small amounts of glauconite occur in sample no. 1 and 2. Sample no. 1 contains furthermore a few rounded grains of quartz and quartzite.

The texture of the limestone appears from fotos fig. 2-7 (p. 8-10). Samples no. 2 corresponds closely to no 1 and no. 4 to no. 3 .

The percentage of the components has been determined by integration. The results are reported in table II (p. 12).

The size distribution of particles $>20 \mu$ has been determined by measuring and counting the individual grains. Tables III and IV (p. 13,15) show the numerical results and fig. 8 (p. 14) is a graph of the size distribution. Regarding the lime matrix as a size fraction $(<20 \mu)$ the grain distribution of the total material has been converted from table II and III into those in table V (p. 15) mentioned datas. Using Friedman's (1958, p. 414) »Graph paper for determining sieve-size distribution from thin-section data" the cumulative curves of fig. 9 (p. 17) were finally produced from table $\mathrm{V}$.

\section{Evaluation.}

According to their petrographic properties samples no. 3, 4, 6 and 7 may be classified as authocthonous sediments, while the prevailing faunal remnants suggest 
the term bryozoan limestone. The environment of deposition has obviously been that of bioherms with bryozoans and little or no water movements at the very sea floor.

Samples no. 1 and 2 are obviously clastic limestones of lime sand or calcarenite type. It is assumed that the material was deposited in the coast zone of the Danian Sea.

Sample no. 5 is apparently also a clastic limestone; the grain size suggests lime silt.

Sample no. 8 is regarded as a transition type between the authocthonous limestones and the clastic limestones.

Following the terminology of FaIrbridge (1955, p. 45) all the investigated limestones may be classified as different members of a »biohermal suite« or »complex». 


\section{Litteratur}

D.G.U.: Danmarks Geologiske Undersøgelses skrifter; København.

D.G.F.: Meddelelser fra Dansk Geologisk Forening; København.

Andersen, P. E. and B. Huort Petersen, 1961: Drilling of Concrete Cores and Preparation of Thin Sections. Rilem (The International Union of Testing and Research Laboratories for Materials and Structures), Bull. No. 11, pp. 94-106; Paris.

Berthelsen, O., 1962: Cheilostomatous Bryozoa in the Danian Deposits in EastDenmark. D.G.U. II. ser. no. 83 (in press).

Bohlin, B. and V. JaAnusson, 1955: The Lower Ordovician Limestone between the Ceratopyge shale and the Platyurus Limestone of Böda Hamn. Bull. Geol. Instit. of Uppsala. Vol. XXXV pp. 111-173; Uppsala.

Fairbridge, R. W., 1955: Warm Marine Carbonate Environments and Dolomitization. Tulsa Geol. Soc. Digest, Vol. 23, pp. 39-48; Tulsa.

Friedman, G. M., 1958: Determination of Sieve-size Distribution from Thin-section Data for Sedimentary Petrological Studies. Journ. of Geology. Vol. 66 pp. 394-416; Chicago.

Gry, H., 1935: Petrology of the Palecene Seclimentary Rocks of Denmark. D.G.U., II. ser. no. 61.

Gry, H. og B. Søndergand, 1958: Flintforekomster i Danmark. The Occurring of Flint in Denmark. The Danish National Institute of Building Research and the Academy of Technical Sciences. Committee on Alkali Reactions in Concrete. Progress Report D 2; Copenhagen.

Hedberg, H. D., 1954: Procedure and Terminology in Stratigraphic Classification. Congr. Géol. Internat. Compte Rend. 19. Sess., Fasc. XIII, Sect. XIII, P. 1, pp. 205233 ; Alger.

JaAnusson, V., 1955: se Bohlin \& JaAnusson, 1955.

Johnstrup, F., 1882: Oversigt over de geognostiske forhold i Danmark. - Falbe-Hansen og Scharling: Danmarks statistik, Bd. 1; København.

Krumbein, W. C. and F. J. Pettijohn, 1938: Manuel of Sedimentary Petrography; New York.

Larsen, G., 1961: Microscopic Point Measuring. A Quantitative Petrographic Method of Determining $\mathrm{Ca}(\mathrm{OH})_{2}$ - Content in Cement Paste in Concrete. Mag. of Concrete Research. (in press); London.

Madsen, V., H. Odum og H. Gry, 1935: Boringerne ved Langbrogaard ved Sønderborg. D.G.U. II. rk. nr. 55.

Martna, J., 1955: Studies on the Macrourus and Slandrom Formations I. Shell Fragment Frequencies of the Macrourus Formation and Adjacent Strata at Fjäcka, Gräsgård and File Haidar. Geol. För. i Stockholm. Förh. 77, pp. 229; Stockholm. 
Petтijohn, F. J., 1948: Sedimentary Rocks; New York.

Poulsen, E., 1957: Preparation of samples for Microscopic Investigation. The Danish National Institute of Building Research and the Academy of Technical Sciences. Committec on Alkali Reactions in Concrete. Progress Report M 1.; Copenhagen.

Rosenkrantz, A., 1937: Bemærkninger om det ostsjællandske Daniens Stratigrafi og Tektonik. D.G.F. Bd. 9, pp. 199-212.

Rosenkrantz, A. and H. Wienberg Rasmussen, 1960: South-Eastern Sjælland and Mön, Denmark. Guide to Excursions Nos A 42 and C 37, Part 1, Internat. Geol. Congress. XXI Sess., Norden; Copenhagen.

Rørdaм, K., 1897: Kridtformationen i Sjælland i Terrænet mellem København og Køge og på Saltholm. D.G.U. II. Rk. Nr. 6.

Sorgenfrei, Th., og O. Berthelsen, 1954: Geologi og vandboring. D.G.U. III. rk. nr. 31.

Troelsen, J., og Th. Sorgenfrei, 1956: Principcrne for stratigrafisk inddeling og nomenklatur. D.G.F. Bd. 13, pp. 145-152.

Twenhofel, W. H., and S. A. Tyler, 1941: Methods of Study of Sediments; New York and London.

Wanless, H. R., W. G. Ziebell, E. A. Ziemba and A. Carozzi, 1957: Limestone Texture as a Key to Interpreting Depth of Deposition. Congr. Gcol. Intern. XX a Sesión, Sec. V, I. Tomo, pp. 65-82; Ciudad de México.

Øрum, H., 1926: Studier over Daniet i Jylland og paa Fyn. D.G.U. II. Rk. Nr. 45. 